\title{
Национальное видение мира в творчестве якутских русскоязычных поэтов (на примере поэзии Петра Черных-Якутского и Алексея Михайлова)
}

Николаева Э.Э., учащаяся, ГБОУ РС (Я) «ЭШИ Арктика», 2. Нерюнгри

Научный руководитель: учитель истории Пестряков Г.Д.

Творческие искания П. Черных-Якутского литературоведы по праву определяют, как основополагающие тенденции развития якутской поэзии, по достоинству оценивают серьезный вклад поэта в культуру якутского народа. Действительно, большинство опубликованных и оставшихся в рукописях произведений автора посвящено радостям и страданиям, счастью и трагедиям в родной земле. Например, «Зимняя мелодия», «Родина», «Родная картинка», «Охотску», «Минувшее», «Камелек» и т.п.

На творчество П. Черных-Якутского оказывала огромное влияние русская классическая литература и якутский народный эпос. Имеется немало фактов, подтверждающих то, что поэт был большим знатоком и поклонником якутского устного народного творчества . Будучи еще мальчиком, П. Черных ездил с матерью к своим родственником и там с упоением погружался в завораживающие рассказы народного сказителя. Мотивы якутского олонхо послужили метафорической и символической основой произведения как «Хаан Дьаргыстай». Образы, навеянные якутским эпосом и уникальным мастерством сказителей из народа, не покидали поэта всю жизнь. Это заметно во многих его произведениях. Значительное время своей творческой деятельности Черных-Якутский уделял изучению героического эпоса, былин и сказок

Художественное наследие П.Н. Черных-Якутского, возникшее на стыке исторических эпох и на основе диалога культур и языков, представляет самостоятельный этап в становлении русскоязычной литературы Якутии, отражает основные тенденции развития национальной художественной словесности

Поколение отечественных поэтов, к которому принадлежит якутский русскоязычный поэт Алексей Константинович Михайлов (1946-1994), вошло в литературу во время «оттепели» 1960-х гг.

А. Михайлов часто обращается к поэтике якутского народного стихосложения, к форме и ритму якутских народных песен, обрядовой поэзии, фольклорным образом. Важным свойством творческой поэзии А. Михайлова является совмещение фактов духовной и материальной культуры двух народов, их нравов, обычаев, мировоззрения и образа жизни.

Еще одна черта национального своеобразия поэзии А.К. Михайловаизображение самобытного характера якутского народа. Гостеприимство как особенность менталитета народа саха подчеркнуто в стихотворении «Приходите, я вас жду ...», проникнутом народным представлением о щедрости сердца, открытости души всем людям:

Приходите, я вас жду

во дворе снега белеют 
И в печи дрова алеют.

Приходите, я вас жду.

Вот стоят мои сэргэ

Старым мастером точены,

Снегом и дождем мочены,

Вот стоят мои сэргэ.

Стройнозвучный мой хомус

Звук его- ручья теченье

И стрелы летящей пенье.

Стройнозвучный мой хомус .

Мы считаем, что первым крупным двуязычным писателем стал П. ЧерныхЯкутский обратившийся в своем творчестве русским и якутским языкам. В его поэзии чувствуется ярко выраженное якутское национальное начало, что позволяет назвать его якутским поэтом, писавшим на русском языке. Наиболее плодотворным было творчество на русском языке А. Михайлова. Анализ произведений показал о глубинных творческих поисков писателя. Он сумел средствами русского языка передать национальный дух, взглянуть на мир «глазами своей национальной стихии». У поэтов П. Черных- Якутского и А. Михайлова описание традиций, обычаев якутского народа, воспевание красоты родной земли, изображение самобытного характера якутов проявляется в использовании традиционной народной символики образов снега, солнца, огня, реки, стерхов, обращением к сюжетам и героям олонхо.

Список литературы:

1. Артемьев В. Найдены новые документы и рукописи П.Н. Черных [Текст] /В. Артемьев // Ургэл. - 1991. - № 2 . - С. 23 - 24.

2. Куклина Е. Мотив снега [Текст] / Е. Куклина // Полярная звезда. - 1995. - №5.

3. Михайлова М.Г. Русская литература в Якутии: монография [Текст] / М.Г. Михайлова. - Якутск, 1989. - 112 с.

4.Михайлов А.К. Снег: поэтический сборник [Текст] / А.К. Михайлов. - Якутск, 1977.

5. Михайлов А.К. Звезды в инее: поэтический сборник [Текст] / А.К. Михайлов. - Якутск, 1981.

6. Михайлов А.К. Снег в Якутске: поэтический сборник [Текст] / А.К. Михайлов. - Якутск, 1980.

7. Михайлов А.К. От утренней звезды и до звезды вечерней: поэтический сборник [Текст] / А.К. Михайлов. - Якутск, 1993.

8. Петр Черных-Якутский [Текст] // Хотугу Сулус - 1982 г. - № 3 - 91 - 92 с.

9. Сергеева А. Певец родного края [Текст] / А. Сергеева // Полярная звезда. 1982. - № 2.

10. Сивцева Н. Явление двуязычного художественного творчества современном поэзии Якутии [Текст] / Н. Сивцева //Полярная звезда. - 1995. - № 3.

11. Тарский Г.С. П. Черных-Якутский. Очерк жизни и творчества [Текст] /Г.С. Тарский. - Якутск: Якуткнигоиздат , 1964. - 3-15 с. 